plosives. It is well, therefore, not to have exaggerated ideas of the power of explosives or to be unduly scared by the threat of explosives dropped from Zeppelins. The destructive effect of the large charges which can be fired from the huge howitzers used in the present war is terrible, but explosives have their limits.

While without doubt the damage done locally from the explosion of a large quantity of any explosive which might be dropped by a Zeppelin would be appalling enough, yet, judging from the effects of the accidental explosion of a couple of tons of nitroglycerine during manufacture, its area would be comparatively restricted, and the horrifying suggestions mooted of the coming total destruction of cities by explosives dropped from the sky may be ascribed to the imagination of the over-credulous.

W. Macnab.

PROF. INGRAM BYWATER.

$\mathrm{O}$ December 18 there died in his house in Onslow Square the greatest Greek scholar of our time. Ingram Bywater was remarkable for the fact that he was imbued with the scientific spirit, and pursued the investigation of Greek thought - what may be called "the Greek thing" -in the true scientific method. He was in close sympathy with scientific men engaged in other branches of investigation, of the methods and results of which he had a remarkable understanding and appreciation.

Bywater was born in 1840 , and after early days spent at University and King's College Schools, became a scholar of Queen's College, Oxford; then, in 1863 , fellow and tutor of Exeter College. On the death of Jowett in 1893 he was appointed by Mr. Gladstone Regius Professor of Greek. It was chiefly through Bywater's influence that Exeter College was led to offer in 1872 a fellowship in the competition for which biology was to be the chief subject. Huxley and Rolleston acted as examiners on behalf of the College, and I had the good fortune to be the successful candidate. My college rooms were adjacent to Bywater's, and we became constant companions and friends. We often discussed--when the college slumbered-the life and learning of the world and our own special studies in a tobacco-parliament of two during the small hours of the night. I learnt more from him than I can say, and not only enjoyed his wise and humorous discourse and his freedom from pedantry, but formed a warm regard for his fine spirit, his wide learning, and his intellectual veracity. When my fellow-student Moseley-who had not competed for the Exeter fellowship owing to his appointment as naturalist on the Challenger expedition-returned from his travels, Bywater proposed that the college should elect him also to a fellowship, which was done.

In 1885 Bywater married the second daughter of Mr. C. J. Cornish, of Salcombe Regis, widow of Mr. Hans Sotheby, a former fellow of Exeter College. The work of her nephews, Charles and Vaughan Cornish, is well known to scientific No. 2356 , vol. 94$]$ naturalists. Bywater was singularly happy in his marriage, and after the death of his wife in 1908 never recovered his strength and vivacity. $\mathrm{He}$ resigned his professorship, but still gave his services to the University in connection with the Bodleian and the Press. He lived among his books in his London house, where after my own departure from Oxford in 1898 I was his neighbour and constantly with him as in the old days at Exeter College.

He had a most unfavourable opinion of the study of Greek as conducted under the examination and scholarship system at Oxford. "It is not Greek which they study," he said, "but an arbitrary and unrea! creation of the examination system and the traditions of college tutors." $\mathrm{He}$ complained that when he was professor even those more serious students among the undergraduates who might have profited by his teaching were by college directors of study kept away from his class-room, as they were in earlier days held back from the lectures of Max Müller. Bywater published in 1880 a remarkable piece of research and discovery relating to the fragments of the Greek philosopher Heracleitus, which led to his election as corresponding member of the Royal Academy of Sciences of Berlin. He devoted many years to the criticism of the text of the "Ethics" and the "Poetics" of Aristotle, and in 1899 the Clarendon Press published his magnum opus, containing his recension of the text of the "Poetics" with an introduction, translation, and commentary. But the young college tutors had the power' of directing their pupils "not to waste their time" with listening to this great and original investigator, and, instead, to work up their Greek in the examination classes of the colleges; and they exercised it! Such is the mischievous result of the English university dry-rot-the examination system.

Only a month ago when my friend had temporarily rallied from the illness which has now ended fatally, he discoursed to me in his characteristically cautious yet vigorous style of German (more especially Prussian) arrogance and intrigue and the boasted "Kultur" of the Germans. He said that the quality of their abundant work, never very high, had deteriorated since 1870 , and contrasted their grasping and pretentious attitude at the International Conference of Academies in Vienna, where he represented the British Academy, with the charm and refinement of the leading Austrian delegate, Prof. Suess, the geologist, now also gone from us, who, he declared, justified his name by the sweetness of both his nature and his behaviour.

E. Ray Lankester.

\section{SCIENCE IN WARFARE.}

$W^{E}$ reprint from the Daily Mail of December 18 a communication to that journal from a Belgian man of science showing how the Germans are utilising science for their operations in the newly conquered region in Belgium.

Here is a great lesson for us, for our Government cares too little for the nation's need for 